\title{
Legitimasi Majelis Ulama Indonesia (MUI) dalam Kontestasi Islam Politik Mutakhir
}

\author{
Mohamad Baihaqi \\ Universitas Islam Negeri (UIN) Sunan Kalijaga Yogyakarta, 55281, Indonesia \\ *email: mohamadbaihaqi91@gmail.com
}

\begin{abstract}
Abstrak
Sejak Presiden Soeharto, organisasi Islam di Indonesia telah diakomodasi oleh Majelis Ulama Indonesia (MUI). Meskipun sejumlah tokoh dalam dua organisasi Islam terbesar Indonesia seperti Nahdlatul Ulama dan Muhammadiyah seringkali tidak sejalan dengan kebijakan MUI. Namun peran MUI dalam politik Islam sejak era orde baru hingga reformasi berlangsung secara dinamis. Para pengurus MUI terikat dengan institusi juga memainkan sentimen keagamaan melalui dua jenis alat legitimasi, yaitu fatwa dan wacana. Dalam pemilihan umum serentak 2019, sejumlah pejabat MUI terlibat aktif dalam kontestasi. Para pengurus MUI juga berbeda pilihan politik. Perbedaan pilihan politik berdampak pada polarisasi di tengah masyarakat yang berpotensi memicu konflik di tingkat akar rumput.
\end{abstract}

Kata Kunci: Legitimasi, Majelis Ulama Indonesia, Islam politik

\begin{abstract}
Since President Soeharto, Islamic organizations in Indonesia have been arrested in the Indonesian Ulema Council (MUI). Although a number of figures in the two largest Indonesian Islamic organizations such as Nahdlatul Ulama and Muhammadiyah are often not in line with MUI policies. But the role of MUI in political Islam since the new order until the reform took place dynamically. MUI administrators who are strongly bound by their institutions also play religious sentiments through two types of legitimacy tools, namely fatwas and discourse. In the 2019 simultaneous general elections, a number of active MUI officials played an important role. MUI administrators differed in political choices, which led to disagreement. This fatigue has an impact on the polarization of the people which has the potential to trigger conflicts at the grassroots level.
\end{abstract}

Keywords: Legitimacy, Indonesian Ulema Council, political Islam

\section{Pendahuluan}

Masyarakat Indonesia adalah masyarakat religius yang meletakkan agama sebagai panduan hidup berbangsa dan bernegara. Islam sebagai agama mayoritas di Indonesia telah mengakar kuat dalam berbagai bidang kehidupan. Terbentuknya pelbagai organisasi Islam di Indonesia terikat kuat dengan sosiologi beragama masyarakat.

Charles Kimball melihat agama sebagai kekuatan yang paling kokoh dan meresap di bumi. Sepanjang sejarah, gagasan dan komitmen keagamaan telah mengilhami individu dan komunitas iman untuk melampaui kepentingan pribadi 
yang sempit dalam mengejar nilai dan kebenaran yang lebih tinggi. Catatan sejarah menunjukkan kasih sayang, pengorbanan diri, dan pelayanan yang mulia kepada orang lain sering kali berakar pada pandangan keagamaan yang dipegang kuat (Kimball, 2002).

Namun, saat melakukan penelitian lapangan di Indonesia, Jennifer L. Epley melihat satu stigma umum yang menganggap bahwa agama dapat menjadi alat untuk politik dan sebaliknya. Walaupun agama tidak secara seragam atau teratur memengaruhi perilaku politik mayoritas Muslim Indonesia. Ada pengakuan luas bahwa para politisi perlu menggunakan simbol-simbol, retorika, dan praktik religio politik tertentu untuk mendapatkan dukungan massa. Epley kemudian menelaah penggunaan agama untuk tujuan politik dan sejauh mana masyarakat umum responsif terhadap klaim dan tindakan mereka (Epley, 2010).

Kuatnya pengaruh agama dalam masyarakat inilah yang menyebabkan organisasi Islam kerap terlibat aktif dalam kontestasi politik Indonesia kontemporer. Salah satu lembaga keagamaan di Indonesia yang mengakomodasi organisasi-organisasi keislaman tersebut adalah Majelis Ulama Indonesia (MUI). Dalam tesis Muhammad As'ad Majelis Ulama Indonesia (MUI) didefinisikan sebagai organisasi semi-pemerintah di Indonesia yang salah satu tujuannya adalah untuk memberikan saran dan fatwa tentang agama dan masalah bangsa kepada pemerintah dan masyarakat. Selain itu, MUI juga diharapkan turut mempromosikan persatuan di antara umat Islam, dan bertindak sebagai mediator antara pemerintah dan ulama (As'ad, 2010).

Dalam Pemilihan Presiden (Pilpres) 2014 lalu, peran pengurus MUI tak sekuat dalam Pilpres 2019. Dalam kontestasi politik 2014 tidak ada calon presiden dan wakil peresiden yang aktif di lembaga keagamaan. Sedangkan pada pemilihan umum 2019 ketua umum MUI, KH. Ma'ruf Amin ditunjuk sebagai calon wakil presiden mewakili petahana. Artikel ini bermaksud untuk mengkaji peran MUI dan pengurusnya dalam Pilpres 2019, kepercayaan masyarakat Muslim terhadap MUI ada Pilpres 2019, dan dampak dari keterlibatan aktif pengurus MUI dalam politik praktis.

\section{Metode Penelitian}

Artikel ini menggunakan metode penelitian kualitatif-deskriptif analitis dengan menggunakan data primer dari buku, tesis, disertasi dan dilengkapi laporan media massa. Terdapat tiga referensi primer yang dianggap relevan untuk menyorot persoalan agama (Islam), Indonesia dan peran MUI. Ketiga referensi tersebut ialah "When Religion Become Evil" dari Charles Kimball, Disertasi Jennifer L. Epley, "Voice of The Faithful: Religion and Politics in Contemporary Indonesia", dan Tesis Muhammad As'ad, "Religion and Politics In Indonesia Attitudes and Influences of The Indonesian Council of Ulama (MUI) on The General Election".

Di samping itu, tulisan ini diperkaya dengan berbagai referensi sekunder untuk melihat perspektif dan materi dari pelbagai penilitian lainnya. Referensi dari sumber lain berguna untuk membandingkan pola dan perspektif lain tentang agama dan peran ulama Indonesia dalam kontestasi politik mutakhir. Karena itu penulis memilih menggunakan pendekatakan sosiologi politik yang memfokuskan pembahasan pada gerakan-gerakan Majelis Ulama Indonesia (MUI) dan 
pengurusnya. Pendekatan tersebut difokuskan untuk mengamati persoalan Islam politik mutakhir. Lewat pendekatan Sosiologi ini akan dikupas perilaku dan pandangan politik masyarakat terhadap Islam Politik dan tokoh-tokoh politikagama di Indonesia, khususnya dalam kontestasi Pemilihan Presiden (Pilpres) 2019.

Sosiologi politik melingkupi persoalan pandangan dan pikiran, perilaku, institusi Islam politik, partisipasi politik, dan marketing politik (Qodir, 2012). Pendekatan sosiologis semacam ini kerap digunakan dalam persoalan yang lebih mikro, yakni tentang perilaku politik masyarakat. Dalam koenteks tersebut maka sosiologi politik Islam di sini akan mengamati hubungan masyarakat dan peran institusi Islam yang secara tak langsung menggunakan agama sebagai domain penting. Itu sebabnya terminologi Islam Politik dianggap lebih tepat dibandingkan Politik Islam.

Lewat pendekatan tersebut, penelitian ini melihat bagaimana legitimasi yang dimainkan oleh berbagai tokoh agama lewat institusi keagamaan semi pemerintahan seperti MUI. Legitimasi dalam pengertian Peter L. Berger kerap digunakan untuk menguatkan posisi tokoh agama dalam kehidupan sosialnya. Berger mendifinisakan legitimasi sebagai "pengetahuan" yang diobjetivikasi secara sosial yang bertindak untuk menjelaskan dan membenarkan tatanan sosial. Dengan kata lain legitimasi adalah jawaban terhadap pertanyaan-pertanyaan "mengapa" mengenai susunan kelembagaan. Termasuk apa saja pengetahuan dalam suatu kolektivitas masyarakat tertentu. Di saat yang sama lembaga-lembaga melegitimasi aktivitas manusia (Berger, 1991).

Tujuan pokok legitimasi adalah pemeliharaan realitas baik pada tingkat obyektif maupun subyektif. Agama lewat lembaga keagamaan melegitimasi masyarakat. Karena agama menghubungkan konstruksi-konstruksi realitas rawan dari masyarakat empiris dengan realitas purna. Realitas rawan dunia sosial itu didasarkan pada realissimum keramat (sakral) di luar dari makna-makna aktivitas manusiawi (Berger, 1991). Teori-teori sosiologi agama dibutuhkan untuk melihat bagaimana agama berkerja dalam masyarakat dan mempengaruhi perilaku pemilih.

\section{Pembahasan}

\section{Melihat Agama Bekerja: Monopoli Kebenaran}

Pada dasarnya agama dihadirkan untuk mengatur kehidupan umat manusia. Agama menjadi semacam perisai dan tata nilai dalam kehidupan sosial. Di samping memiliki nilai kekudusan yang mendorong manusia untuk bersikap spritual. Berkat kekuatan spritual itulah, manusia diharapkan menjadi paripurna. Hubungan dengan Tuhan yang didorong oleh keimanan memberi semacam etik dalam kehidupan sosial, politik dan ekonomi. Sebab itu dalam agama, anjuran berlaku mulia dalam kehidupan sosial menjadi ajaran utama.

Idealnya agama sebagai semacam panduan yang menuntun kehidupan manusia ke dalam kebahagiaan yang bersifat fisik dan metafisik. Agama lahir tentu saja sesuai konteks masyarakat di mana agama-agama diturunkan. Sebab itulah agama di satu sisi dapat membangkitkan sebuah praktik dalam kehidupan sehari-hari. Tindakan di dalam kehidupan sosial pun melibatkan kalam Tuhan. 
Hal-hal yang bersifat transendental seperti ibadah sehari-hari menjadi semacam fakta sosial yang tak bisa terelakkan (Kimball, 2002).

Persoalannya adalah ketika tindakan hadir, maka tindakan tersebut menjadi representasi hasil tafsiran manusia tentang perintah Tuhan. Manusia akhirnya bertindak dalam persepsi nya masing-masing. Dalam kehidupan spritual tersebut, pengalaman pribadi juga ditafsirkan dalam kerangka transenden. Saat agama sudah menguat secara individu pada akhirnya agama menjadi semacam kekuatan kolektif yang terorganisir. Tindakan kolektif menonjol dalam kehidupan sosial dengan pelbagai bentuknya.

Legitimasi kekuasan duniawi lewat institusi politik dengan memanfaatkan keyakinan dan simbol-simbol religius memiliki sejarah panjang dan kompleks. Politik abad tengah di Eropa misalnya difokuskan pada masalah legitimasi yaitu pihak manakah yang melegitimasi kekuasaan agar bisa dijalankan. Masyarakat di Abad pertengahan menghadapinya lewat dua pendekatan yaitu gagasan menurun dan gagasan mendaki. Gagasan menurun yaitu kekuasan yang diturunkan oleh Tuhan melalui agama-agama. Sedangkan kekuasaan mendaki yaitu dari masyarakat ke Tuhan. Tesis mendaki secara kronologis mendahului konsep menurun, diidentikkan lewat dewan-dewan masyarakat. Para pemimpin suku atau masyarakat pada awalnya tidak memiliki kekuasaan apa-apa. Selain masyaarakat memberikan semacam kekuasaan padanya. Karena mereka dianggap sebagai wakil dari rakyat (Turner, 2012).

Dalam pola demikian, kepala-kepala suku dilihat dan dipercaya oleh masyarakat karena dianggap memiliki pengaruh antara lain dilihat karena ketaatannya terhadap ajaran agama. Dengan demikian masyarakat pun memberikan kepercayaan kepada tokoh tertentu yang dianggap mampu memegang kepercayaan dengan indikator kedekatannya dengan Tuhan. Sementara itu dalam teori menurun legitimasi penguasa berasal dari Tuhan dan karenanya masyarakat tidak memiliki hak untuk melawan dan tidak berdaya di hadapan raja. Penguasa dianggap memiliki otoritas dan bertanggungjawab penuh kepada Tuhan, bukan kepada rakyat (Turner, 2012). Prinsip menurun ini terkristalisasi dalam teori pemerintahan teokrasi, kekuasaan didistribusikan ke bawah melalui pejabatpejabat resmi yang bertanggungjawab kepada raja bukan kepada masyarakat yang dipimpin.

Sementara itu di Indonesia berdiri di atas prinsip-prinsip Pancasila yang berada di titik liminal yakni antara negara teokrasi dan negara sekuler. Sila pertama dalam Pancasila menegaskan pentingnya ketuhanan sebagai pondasi berbangsa. Sementara di satu sisi Indonesia tidak menerapkan formalisasi hukum agama tertentu. Namun sosiologi masyarakat Indonesia sangat menekankan pentingnya peran tokoh agama dalam politik Indonesia bahkan sejak pra kemerdekaan.

Dalam sejarahnya, Sarekat Islam membagi masyarakat menjadi beberapa kelompok antara lain golongan ambbteenar Belanda, golongan Cina, golongan bangsawan dan golongan Indonesia pada umumnya (Kuntowijoyo, 2017). Sejak awal SI mendefinisikan diri sebagai suatu kelompok kelas sosial berbasis agama. Sebelumnya periode awal SDI merumuskan diri sebagai kelompok dagang dan sejak itu ideologi Islam mulai ditanamkan di dalam kesadaran umat.

Kesadaran umat tersebut pada awalnya lahir secara personal, di luar hubungan institusional kelembagaan, Charles Kimball (2002) menjelaskan 
bagaimana agama bekerja mempengaruhi individu hingga ke kolektif dengan pernyataanya:

Most people, for instance, assume that religion involves human thinking about or engagement with God, gods, or some less personal understanding of ultimate reality. They might well envision individual or communal responses to the transcendent, such as prayer, worship services, rituals, moral codes, and so on. Some people naturally think immediately of the life and teachings of Jesus or the Buddha when they think of religion; others might picture the pope or Billy Graham or Mother Teresa in their mind's eye. To complicate the picture further, personal experiences factor in as well. An individual may think of her confirmation or his bar mitzvah. If she or he has had some negative personal history with "organized" religion, then that, too, will surely figure prominently into the presuppositions.

Namun pada saat yang sama, sejarah dengan jelas menunjukkan bahwa agama sering dikaitkan langsung dengan contoh-contoh terburuk perilaku manusia. Lebih banyak perang telah terjadi, lebih banyak orang terbunuh, dan akhir-akhir ini lebih banyak kejahatan dilakukan atas nama agama daripada oleh kekuatan institusional lain dalam sejarah manusia (Kimball, 2002).

Apakah setiap agama menyimpan watak bencana? Kimball dalam bukunya menggariskan lima indikator agar pemeluk agama tidak terjerumus menjalankan agama sebagai bencana. Lima indikator tersebut antara lain, klaim kebenaran dalam setiap agama, fanatisme buta, nostalgia zaman emas agama-agama, menghalalkan segala cara untuk tujuan politik, seruan perang suci (jihad).

Namun pandangan Kimball yang meringkus agama dalam wajah menyeramkan secara mono tafsir dengan wajah militeristiknya merupakan pandangan simplistis. Padahal agama-agama pada dasarnya lahir untuk mendakwahkan kebaikan. Islam misalnya hadir dalam berbagai wajah dan pemahamam, mazhab, dan corak masyarakat. Menurut Ali Harb, tidak ada metode untuk dapat menangkap makna yang masih bersemayam di atas langit. Di dalam emosi dan kalkulasi rasio. Pandangan yang menyebut Islam berwajah tunggal, kesatuan makna atas tafsir adalah pandangan yang didasari oleh a priori semata dan penipuan terhadap satu substansi. Ada pemulaan dan penutupan perbedaan dan penentangan. Apa yang sesuai dengan Islam akan sesuai juga bagi agama lain, baik agama lama maupun baru, agama langit maupun agama bumi (Harb, 2012).

Ketika mereka berbicara tentang Islam yang satu dan benar tentu masih diuji dan dicari relevansinya dengan kondisi kekinian. Pada akhirnya posisi mereka hanya akan membelenggu orang yang berbeda dengan orang lain. Cara yang digunakannya adalah mengasingkannya dari orang lain dan menuduhnya dengan predikat penentang dan pemberontak (Harb, 2012).

\section{Islam Politik Indonesia Kontemporer}

Populasi penduduk Indonesia sebesar 237,512,352 jiwa yang terdiri dati penduduk Muslim Indonesia sebesar 86.1\%, Protestan 5.7\%, Katolik 1.8\%, Hindu $3.4 \%$, dan sisanya aliran kepercayaan lainnya menyebabkan Indonesia sebagai pemeluk Islam terbesar di Indonesia (Epley, 2010). Itu sebabnya peran organisasi Islam sangat penting dalam konteks meraup suara konstituen. Sedangkan partai 
Islam menyandarkan basis massanya pada jamaah dari organisasi keislaman tersebut.

Heterogenitas Islam di Indonesia tidak melarang identifikasi pola. Jennifer melihat pribadi dan komponena sosial yang dipilih dari identitas keagamaan yang memengaruhi partisipasi pemilih dan perilaku. Meskipun agama penting bagi umat Islam, biasanya agama tidak secara langsung atau teratur memengaruhi mayoritas orang Indonesia untuk mengambil tindakan politik, terutama di luar pemungutan suara. Ada minoritas aktif yang menganggap Islam relevan (Epley, 2010).

Jennifer menekankan peran tokoh berdasarkan identitas keagamaan sangat berpengaruh penting dalam politik Indonesia kontemporer. Lewat pengaruh tokoh agama semacam ini, partisipasi dan perilaku pemilih dapat dipengaruhi. Identitas Muslim Indonesia beragam dan cair. Agama itu sendiri tidak monolitik atau seragam. Komponen pribadi dan sosial nasional yang berbeda dari agama dapat berdampak besar bagi perilaku politik (Epley, 2010).

Sementara itu, Saiful Mujani (2007) melihat kombinasi dari berbagai bentuk keterlibatan politik dan kepercayaan pada institusi politik menghasilkan empat tipe warga negara. Empat tipe tersebut yakni: setia, teralienasi, naif dan apatis. Warga yang teralienasi yakni yang tertarik pada politik tapi tidak percaya dengan institusi politik. Tipe ini menjadi sumber destabilisasi demokrasi. Aktivitas politik tersalurkan lewat aksi protes. Perilaku tersebut mengganggu stabilitas sistem demokrasi.

Perdebatan tentang keterkaitan umat Muslim dalam politik sudah menjadi perbinjangan lama. Abdul Munir Mulkan mengklasifikasi perdebatan tersebut ke dalam dua kategori. Kategori pertama, umat Muslim melihat politik sebagai wilayah profan yang terbuka bagi partisipasi publik tanpa memandang identitas keagamaan. Kedua, melihat dunia politik sebagai realisasi ajaran agama (Islam) yang absolut dan dikuasai oleh elit agama dengan sebutan ulama (Mulkhan, 2009).

Idealnya, legitimasi moral seorang pemimpin Islam sejati terletak pada kualitas Muslim itu sendiri. Kesatuan antara perbuatan dan perkataan, rendah hati, jujur. Pemimpin semacam itu berorientasi bagi perbaikan hajat hidup masyarakat luas. Segala yang dimiliki pemimpin (Islam) dicurahkan untuk membangun bangsa (Jurdi, 2008).

Di sanalah peran ulama dalam lembaga-lembaga keagamagaan sangat berpengaruh dalam Islam politik di Indonesia. Salah satu lembaga yang mengakomodasi berbagai organisasi keagamaan di Indonesia adalah Majelis Ulama Indonesia (MUI). Dalam perhelatan pemilu 2019 lalu, MUI memainkan peran penting yang secara tidak langsung dimainkan oleh beberapa pengurus aktifnya. Di Indonesia peran MUI dalam politik memang sudah lama berlangsung.

\section{MUI Dari Masa Ke Masa}

Menurut As'ad, (2010) dalam menjalankan fungsi tersebut, MUI memiliki alat tertentu untuk memberikan panduan kepada masyarakat. Setidaknya ada dua jenis media yang digunakan oleh MUI untuk memberikan panduan kepada masyarakat. Meski sebagian besar masyarakat berpendapat bahwa sikap MUI sering terburu buru. Beberapa tokoh publik, termasuk wakil presiden Jusuf Kalla pernah mengkritik MUI dan merasa tidak senang dengan pendiriannya. 
Dua jenis alat legitimasi tersebut adalah fatwa dan wacana. Wacana terdiri dari Rekomendasi (Tausiyah), Peringatan (Tadzkirah), Instruksi/Amanat (Amanah), Pernyataan Sikap, Banding (Himbauan), dan Pemikiran (Sumbangan Pemikiran) (Ichwan, 2005). Sedangkan fatwa memainkan peran penting dalam masyarakat. Sebagaimana dinyatakan oleh Wael Hallaq, fatwa memainkan peran yang cukup besar dalam pertumbuhan dan perubahan bertahap hukum substantif Islam (As'ad, 2010).

Dalam hal otoritas agama, fatwa juga penting karena melalui media ini para MUI dapat mengekspresikan gagasan dan pendapat mereka mengenai hukum Islam (As'ad, 2010). Dalam menggunakan fatwa yang diproduksi oleh ulama, orang mungkin tahu apa yang dilarang untuk mereka dan apa yang tidak. Dalam hal ini, fatwa berfungsi sebagai bukti bahwa ulama (atau otoritas agama) memiliki kemampuan untuk memberikan arahan kepada umat Muslim Indoneisa (As'ad, 2010).

Dalam tesisnya, Muhammad As'ad memilah sikap MUI sebagai orgnasisasi ke dalam dua tahapan yakni masa awal pembentukannya saat rezim orde baru berlangsung dan kedua saat reformasi. Pada awal pembentukannya, sikap MUI di era Orde Baru tidak selalu berada di tangan pemerintah; setelah 1982 MUI berada di bawah kendali pemerintah. Penerbitan pernyataan MUI dalam pemilihan umum dimulai pada tahun 1977 dan kemudian berlanjut pada tahun 1982, 1987, 1992, dan 1997. Meneliti kelima tahapan tersebut menunjukkan bahwa hanya pada tahun 1977 MUI tidak memberikan dukungan yang mencolok kepada pemerintah (As'ad, 2010).

Pada tahun-tahun berikutnya, dari 1982 hingga 1997, MUI jelas mendukung pemerintah. Tiga pernyataan (1982, 1992 dan 1997) menyebutkan nama Soeharto untuk melanjutkan posisinya sebagai Presiden Indonesia. Pada tahun 1987, meskipun MUI tidak menyebut Soeharto, ia menyatakan perlunya melanjutkan pemerintahan Orde Baru dan pentingnya partisipasi Muslim Indonesia dalam pemilihan (As'ad, 2010). Kuatnya posisi Islma politik saat itu, dapat dikatakan merupakan imbas dari keterlibatan pemerintah dalam Islam politik yang tidak sekuat pada tahun 1980 dan seterusnya.

Pada masa Reformasi sikap MUI malah berbeda. MUI mengubah posisinya dari mendukung pemerintah menjadi mendukung partai-partai Islam. Sikap ini dipengaruhi oleh melemahnya kekuatan pemerintah. Berbeda dari era Orde Baru, ketika kekuatan politik pemerintah sangat kuat, era Reformasi dicatat sebagai titik awal dari debat terbuka di mana kebebasan berbicara sangat dihormati. Perubahan ini, pada gilirannya, juga mempengaruhi sikap MUI yang segera mendukung partai-partai Islam dengan menyatakan bahwa umat Islam harus memilih hanya untuk kandidat Muslim. Selain itu, rekomendasi menunjukkan kembalinya aliran politik (politik aliran) yang terjadi hanya dalam pemilihan umum 1955. Selama era Orde Baru, aliran politik tidak muncul karena tekanan pemerintah yang menerapkan Pancasila sebagai prinsip dasar tunggal.

Rekomendasi ini juga menunjukkan melemahnya kekuatan MUI dari pengaruhnya terhadap perilaku memilih rakyat Indonesia. Kemenangan PDI-P dalam pemilihan umum tahun 1999 menunjukkan bahwa MUI tidak berhasil meyakinkan banyak Muslim untuk memilih partai-partai Islam. Fakta ini jelas mengalahkan salah satu tujuan MUI di balik taushiah pada 1999, yang bertujuan untuk menghambat peluang PDI-P untuk memenangkan pemilihan (As'ad, 2010). 
Pada pemilihan umum 2004 persis sama dengan pemilu 1999 dalam arti bahwa MUI tidak memberikan dukungan nyata kepada pemerintah seperti yang terjadi di era Orde Baru. Hal tersebut juga berbeda dari taushiah MUI dalam pemilihan umum 1999, yang secara khusus mendukung partai Islam dengan menyarankan bahwa Muslim Indonesia tidak boleh memilih calon non-Muslim. Dapat ditafsirkan bahwa sikap MUI dalam pemilihan umum 2004 adalah netral. Posisi ini diadopsi karena dua kondisi. Pertama, partai-partai Islam tidak lagi menggunakan masalah agama (Islam) dalam kampanye mereka. Kedua, semua tiket dalam pemilihan presiden memiliki kandidat (baik untuk presiden atau wakil presiden) dari berlatar belakang Muslim (As'ad, 2010).

Dibandingkan dengan sikapnya dalam pemilihan umum sebelumnya, fatwa MUI pada tahun 2009 tentang abstain suara dapat dianggap sebagai yang paling berbeda dan kontroversial. Sikap ini berbeda karena MUI sebelumnya tidak pernah mengeluarkan fatwa tentang pemilihan umum tetapi hanya memberikan pernyataan atau rekomendasi. Ini juga menjadi kontroversial di antaranya karena reaksi banyak orang Indonesia yang mengkritik fatwa, tetapi juga karena penerbitan itu sendiri. Tidak jelas apakah fatwa.

Dapat ditarik perbedaan sikap MUI di era Orde Baru dan era pasca-Orde Baru (Reformasi). Di bawah Orde Baru, MUI dapat dianggap bermain aman dengan mendukung pemerintah. Selama era itu, hanya dalam pemilihan umum 1977 MUI mengadopsi sikap netral. Pendekatan ini diambil karena tekanan pemerintah yang membatasi pergerakan politik MUI. Di era pasca Baru Orde, sebaliknya, sikap MUI dalam pemilihan umum ditentukan oleh perkembangan politik. MUI mengubah sikapnya dengan menjauhkan diri dari pemerintah dan memperbaiki keputusannya sesuai dengan konteks politik. Pengaruhnya di era Reformasi tidak sekuat seperti di zaman Orde Baru (As'ad, 2010).

Sementara tulisan ini melihat bagaimana posisi politik MUI pada pemilihan presiden 2019 lalu. Apakah MUI berada dalam posisi seperti saat rezim orde baru berlangsung atau mempertahankan sikapnya sebagaimana di era reformasi? Secara kelembagaan MUI tampak tidak secara langsung memainkan peran penting dalam politik Indonesia kontemporer. Namun pengurus aktif di MUI belakangan diketahui terlibat aktif dalam mensukseskan salah satu calon presiden lewat legitimasinya sebagai pengurus MUI. Lantas bagaimana legitimasi tersebut berlangsung di tubuh MUI sendiri?

\section{Peran MUI dalam Politik Indonesia Mutakhir}

Fenomena Islam Indonesia yang sangat beragam menyebabkan perubahan konstelasi politik Indonesia menjadi dinamis karena berbagai macam faktor yang mempengaruhi. Itu sebabnya tidak mudah untuk menempatkan satu kelompok secara absolut. Hal ini karena adanya fakta bahwa kelompok Islam di Indonesia ternyata juga memiliki identitas kelompok lain yang saling meminjam sehingga tampak tumpang tindih. Secara sosiologis merupakan akibat dari percampuran antara masyarakat dan kultur (Qodir, 2012).

Pola semacam itu dapat dilihat dari model kepengurusan MUI yang mencoba untuk mengakomodasi seluruh Organisasi Islam di Indonesia. Sehingga setiap pengurus MUI memiliki keterikatan secara langsung dengan organisasi Islam lainnya seperti Nahdlatul Ulama dan Muhammadiyah. Pada saat yang sama 
baik MUI maupun ormas seperti NU dan Muhammadiyah secara langsung tidak terlibat dalam politik praktis. Hanya saja pengurusnya dibebaskan untuk mendukung salah satu calon bahkan menjadi calon wakil presiden.

Hal tersebut dapat dilihat misalnya di Indonesia, kekuatan agama yang membingkai lahirnya organisasi-organisasi kemasyarakat cukup memiliki otoritas dalam mengarahkan masanya. Ormas keagamaan menjadi semacam kiblat dalam berperilaku lewat anjuran, sikap, serta fatwa yang dikeluarkan oleh organisasiorganisasi keagamaan.

Bentuk pertama organisasi Umat Islam di Indonesia adalah mengelompokkan pribadi-pribadinya di belakang pribadi-pribadi yang berkarisma seperti Kyai dan Haji. Orang-orang yang berkharisma itulah yang kemudian mengarahkan umat untuk melakukan berbagai pemberontakan. Umat Islam terpecah dalam ikatan-ikatan yang sangat kecil di lingkaran yang sangat lokal dan tersebar dimna-mana. Tetapi tidak berarti umat Islam saat itu tidak melakukan Aksi (Kuntowijoyo, 2017).

Umat Islam dalam sejarah Indonesia sebagai ungkapan-ungkapan nasional untuk menghadapi kekuatan-kekuatan kolonial. Islam pada titik itu dianggap sebagai tradisi besar yaitu tradisi yang mampu mengorganisir sebagaimana dalam sejarah Islam ada kekhalifahan dan imperium-imperium Islam. Namun Islam di luar birokrasi di Indonesia hanya sanggup membentuk masyarakat kecil sehingga tidak bisa menyatukan diri dalam kesatuan yang disebut sebagai konsep Umat (Kuntowijoyo, 2017).

Setelah era reformasi, partai Islam senantiasa terlibat dalam pemilu, tidak pernah kurang dari lima. Rata-rata tujuh partai Islam ikut pemilu selama era reformasi 1999-2000. Namun kecenderungan perolehan suaranya kerap menurun. Kondisi semacam itu menegaskan bahwa partai Islam sebenarnya mengalami kemerosotan pamor di mata pemilih (Qodir, 2012). Sementara itu pada pemilihan umum serentak 2019 Partai Kebangkitan Bangsa (PKB) memperoleh suara keempat terbanyak setelah PDIP, Gerindra, dan Golkar.

Kemampuan memobilisasi massa dan elit umat telah mendorong elit birokrat menempatkan konsepsi depolitisasi dan departaisasi sebagai kerangka utama kebijaksanaan politik pemerintah (Mulkhan, 2009). Salah satu organisasi semi pemerintahan yang pengurusnya terlibat aktif dalam politik Indonesia adalah Majelis Ulama Indonesia (MUI). Perannya cukup penting terlebih dalam pemilihan serentak pada 2019 lalu.

Berikut sejumlah pengurus MUI yang diketahui secara terang-terangan berperan aktif dalm kontestasi politik Indonesia 2019. Meskipun beberapa pengurus kerapkali mengeluarkan statmen di media menegaskan bahwa posisi MUI secara kelembagaan bersikap netral. Serta jauh-jauh hari Wakil Ketua MUI, H. Zainut Tauhid Sa'adi mengkhawatirkan gerakan GNPF MUI bergeser ke arah politik praktis. 
Tabel 1. Nama Pengurus Aktif MUI

\begin{tabular}{|c|c|c|c|}
\hline No & Nama & Jabatan & Peran Politik \\
\hline 1 & Prof. Dr. KH. Ma'ruf Amin & Ketua Umum MUI & $\begin{array}{l}\text { Calon Wakil } \\
\text { Presiden }\end{array}$ \\
\hline 2 & Drs. H. Zainut Tauhid Sa'adi, M.Si & Wakil Ketua Umum & \\
\hline 3 & Prof.Dr. H. Yunahar Ilyas, Lc, MA & Wakil Ketua Umum & \\
\hline 4 & Prof. Dr. Hj. Huzaemah T. Yango & Ketua Bidang Fatwa & \\
\hline 5 & Dr. KH. Marsudi Suhud & $\begin{array}{l}\text { Ketua Bidang } \\
\text { Ukhuwah Islamiyah }\end{array}$ & $\begin{array}{l}\text { Simpatisan } \\
\text { Jokowi- } \\
\text { Ma'ruf }\end{array}$ \\
\hline 6 & KH. Abdusshomad Buchori & $\begin{array}{l}\text { Ketua Bidang } \\
\text { Dakwah dan } \\
\text { Pengembangan } \\
\text { Masyarakat }\end{array}$ & \\
\hline 7 & KH. Abdullah Jaidi & $\begin{array}{l}\text { Ketua Bidang } \\
\text { Pendidikan dan } \\
\text { Kaderisasi } \\
\end{array}$ & \\
\hline 8 & Prof. Dr. H. Maman Abdurrahman & $\begin{array}{l}\text { Ketua Bidang } \\
\text { Pengkajian dan } \\
\text { Penelitian }\end{array}$ & \\
\hline 9 & Dr. H. Yusnar Yusuf, M.Si & $\begin{array}{l}\text { Ketua Bidang } \\
\text { Kerukunan Antar } \\
\text { Umat Beragama } \\
\end{array}$ & \\
\hline 10 & Dr. KH Sodikun, M.SI & $\begin{array}{l}\text { Ketua Bidang Seni } \\
\text { Budaya Islam }\end{array}$ & \\
\hline 11 & KH. Muhyidin Djunaidi, MA & $\begin{array}{l}\text { Ketua Bidang } \\
\text { Hubungan Luar } \\
\text { Negeri dan Kerjasama } \\
\text { International }\end{array}$ & \\
\hline 12 & Dr. Ir. Lukmanul Hakim & $\begin{array}{l}\text { Ketua Bidang } \\
\text { Pemberdayaan } \\
\text { Ekonomi Umat } \\
\end{array}$ & \\
\hline 13 & Drs. KH. Masduki Baidlowi & $\begin{array}{l}\text { Ketua Bidang } \\
\text { Informasi dan } \\
\text { Komunikasi } \\
\end{array}$ & \\
\hline 14 & Prof. Dr. Hj. Amany Lubis, MA & $\begin{array}{l}\text { Ketua Bidang } \\
\text { Perempuan, Remaja, } \\
\text { dan Keluarga }\end{array}$ & \\
\hline 14 & Drs. H. Basri Bermanda, MBA & $\begin{array}{l}\text { Ketua Bidang Hukum } \\
\text { dan Perundangan }\end{array}$ & \\
\hline 15 & Drs. H. Anwar Abbas, M.M, M.Ag & Sekretaris Jenderal & \\
\hline 16 & $\begin{array}{l}\text { Drs. KH. Sholahudin Al Aiyub, } \\
\text { M.Si }\end{array}$ & $\begin{array}{l}\text { Wasekjen Bidang } \\
\text { Fatwa }\end{array}$ & \\
\hline & H. M. Zaitun Rasmin, Lc, MA & $\begin{array}{l}\text { Wasekjen Bidang } \\
\text { Ukhuwah Islamiyah }\end{array}$ & $\begin{array}{l}\text { Simpatisan } \\
\text { Prabowo- } \\
\text { Sandi } \\
\end{array}$ \\
\hline
\end{tabular}




\begin{tabular}{|c|c|c|c|}
\hline 18 & H. Tengku Zulkarnaen, MA & $\begin{array}{l}\text { Wasekjen Bidang } \\
\text { Dakwah dan } \\
\text { Pengembangan } \\
\text { Masyrakat }\end{array}$ & $\begin{array}{l}\text { Simpatisan } \\
\text { Prabowo } \\
\text { Sandi }\end{array}$ \\
\hline 19 & Dr. H. Amirsyah Tambunan, MA & $\begin{array}{l}\text { Wasekjen Bidang } \\
\text { Pendidikan dan } \\
\text { Kaderisasi }\end{array}$ & \\
\hline 20 & H. Misbahul Ulum, M.Si & $\begin{array}{l}\text { Wasekjen Bidang } \\
\text { Pemberdayaan } \\
\text { Ekonomi Umat }\end{array}$ & \\
\hline 21 & Dr. H. Amirsyah Tambunan, MA & $\begin{array}{l}\text { Wasekjen Informasi } \\
\text { dan Komunikasi }\end{array}$ & \\
\hline 22 & Prof. Dr. Hj. Valina Singka Subekti & $\begin{array}{l}\text { Wasekjen Bidang } \\
\text { Perempuan, Remaja } \\
\text { dan Keluarga }\end{array}$ & \\
\hline 23 & H. Rofiqul Umm Ahmad, SH, MH & $\begin{array}{l}\text { Wasekjen Bidang } \\
\text { Hukum dan } \\
\text { Perundang-Undangan }\end{array}$ & \\
\hline 24 & $\begin{array}{l}\text { Drs. KH. Sholahuddin Al Aiyub, } \\
\text { M.Si }\end{array}$ & $\begin{array}{l}\text { Wasekjen Bidang } \\
\text { Pengkajian dan } \\
\text { Penelitian }\end{array}$ & \\
\hline 25 & Dr. H. Nadjamudin Ramly, M.Si & $\begin{array}{l}\text { Wasekjen Bidang } \\
\text { Kerukunan Antar } \\
\text { Agama }\end{array}$ & \\
\hline 26 & $\begin{array}{l}\text { Dr. Ir. H. M Nadratuzzaman } \\
\text { Hosen, Ph.D }\end{array}$ & Bendahara Umum & \\
\hline 27 & H. Yusuf Muhammad Martak & Bendahara & $\begin{array}{l}\text { Simpatisan } \\
\text { Prabowo- } \\
\text { Sandi } \\
\end{array}$ \\
\hline 28 & Drs. H. Iing Sholihin, MBA & Bendahara & \\
\hline 29 & H. Burhanudin Mochsen & Bendahara & \\
\hline 30 & $\begin{array}{l}\text { Prof. Dr. HM. Din Syamsuddin, } \\
\text { MA }\end{array}$ & Dewan Pertimbangan & \\
\hline 31 & Prof. Dr. H. Azyumardi Azra & Wakil Ketua DP & \\
\hline 32 & Prof. Dr. H. Nasaruddin Umar, MA & Wakil Ketua DP & \\
\hline 33 & $\begin{array}{l}\text { Prof. DR. H. Didin Hafiduddin, } \\
\text { MA }\end{array}$ & Wakil Ketua DP & $\begin{array}{l}\text { Simpatisan } \\
\text { Prabowo } \\
\text { Sandi } \\
\end{array}$ \\
\hline 34 & Prof. Dr. H. Noor Ahmad, MA & Sekretaris DP & \\
\hline 35 & Dr. H. Bachtiar Natsir & Wakil Sekretaris DP & $\begin{array}{l}\text { Simpatisan } \\
\text { Prabowo } \\
\text { Sandi } \\
\end{array}$ \\
\hline 36 & Drs. H. Natsir Zubaidi & Wakil Sekretaris DP & \\
\hline
\end{tabular}

MUI sebagai semacam organisasi semi pemerintahan, kerap mengeluarkan fatwa-fatwa yang berpengaruh terhadap konstelasi politik Indonesia. Salah satu contoh misalnya terbentuknya Gerakan Nasional Pemangawal Fatwa (GNPF) 
MUI yang terlembagakan kembali menjadi forum alumni 212 setelah sebelumnya berhasil menumbangkan elektabilitas Basuki Tjahaja Purnama (Ahok) sebagai calon petahana Gubernur DKI Jakarta.

Selain itu, pada pemilihan presiden 2019 lalu, ketua MUI KH. Makruf Amin dianggap potensial baik secara popularitas maupun basis massa (elektabilas) menjadi pendampingi petahana Ir. H. Joko Widodo. KH. Ma'ruf Amin dianggap sebagai representasi dari dua kekuatan yakni MUI dan organisasi keagamaan Nahdlatul Ulama. Hingga akhirnya Pasangan Joko Widodo dan Ma'ruf Amin berhasil lolos sebagai pemenang pada pemilihan presiden dan wakil presiden 2019 lalu.

Calon penantang, Prabowo Subianto dan Sandiaga Uno juga didukung oleh berbagai tokoh-tokoh "Islam" yang sebelumnya tergabung dalam GNPF MUI. Sebut misalnya Tengku Zulkarnanen, Bachtiar Nastir, Yusuf Martak, Zaitun Rasmin dan beberapa pengurus MUI lainnya. Mereka kemudian memanfaatkan forum alumni 212 untuk menggalang massa. Reuni 212 beberapa kali dilaksanakan dengan mengundang capres Prabowo Subianto berorasi di mimbar. Selain itu, dalam forum ijtima ulama diputuskan mendukung Prabowo Subianto dan beberapa rekomendasi calon wakil presiden. Kendati seluruh rekomendasi bakal calon wakil Presiden ditolak oleh Prabowo, namun beberapa tokoh yang tergabung dalam forum tersebut tetap bersikukuh mendukung Prabowo Subianto dan Sandiaga Uno.

Dalam pemilihan presiden itulah dapat dilihat bagaimana peran penting sejumlah anggota MUI. Meski tidak mengatasnamakan institusi, namun tokohtokoh dalam tubuh MUI sendiri dijadikan acuan oleh masyarakat Indonesia sebagai pemegang kuasa mendaki-menurun. Akhirnya kedua calon bertarung dalam kontestasi politik dengan sama-sama disokong oleh keterlibatan pengurus MUI.

Dari itu, penting dilacak bagaimana pengurus MUI memainkan sehingga bisa kendali atas suara Muslim di Indonesia. Mereka mengatasnamakan agama sebagai modal untuk meyakinkan masyarakat bahwa calon presiden yang diusung benar-benar "islami". Pada titik itu bagaimana agama bekerja sehingga dianggap begitu efektif dalam meraup suara lewat pengurus-pengurus MUI?

\section{Legitimasi MUI terhadap Umat Muslim}

Kuntowijoyo (2017) menyebut bahwa fenomena Islam Indonesia beragam dalam pemikiran politik dan teologinya. Hal ini karena adanya fakta bahwa satu kelompok Islam di Indonesia ternyata juga memiliki identitas kelompok lain. Di sini akan dipaparkan tiga strategi yang dimainkan MUI dalam perhelatan pemilu 2019 yang dilihat dari peran pengurus aktifnya. Pengurus dan lembaga bagi masyarakat bersifat linier dan terikat.. Pernyataan pengurus MUI dilihat juga sebagai sikap lembaga meski pada pemilihan yang lalu pengurus MUI terbelah dalam dua kubu.

\section{Pengurus Ulama Memainkan Kuasa Menurun-Mendaki}

Di era reformasi ini, strategi Majelis Ulama Indonesia (MUI) berayun. MUI tidak lagi mendukung salah satu calon presiden dan wakil presiden maupun partai politik seperti dalam sejarah panjang peran politik MUI dalam kontestasi islam politik di Indonesia. Kendati demikian dukungan mengalir dari pengurus MUI 
sendiri. Hal itu tak menghilangkan peran kharisma personal sebagai pengurus MUI lewat kekuasaan mendaki (masyarakat-wakil agama-Tuhan). Dengan kata lain individu dalam MUI melekat dengan lembaganya sendiri.

Itu sebabnya, masyarakat menyerahkan seluruh kepercayaannya atas nama agama kepada Para pengurus MUI Inilah yang disebut Bryan S Turner (2012) sebagai kuasa mendaki yang secara kronologis mendahului konsep menurun. Para pemimpin dalam MUI pada awalnya tak memiliki kuasa sebelum masuk dalam pengurusan MUI sendiri.

Dalam pola demikian, MUI dilihat dan dipercaya oleh masyarakat karena dianggap memiliki pengaruh antara lain dilihat karena mewakili nama ulama. Dengan demikian masyaarakat pun memberikan kepercayaan kepada tokoh tertentu yang dianggap mampu memegang kepercayaan dengan indikator kedekataanya dengan Tuhan. Sementara itu diliihat dari perjalanan MUI, kepercayaan masyarakat terhadap MUI belakangan dinilai menurun (As'ad, 2010).

Heterogenitas Islam di Indonesia tidak melarang identifikasi pola. Melihat pribadi dan komponen sosial yang dipilih dari identitas keagamaan yang memengaruhi partisipasi pemilih dan protes perilaku. Karena itu MUI mengubah strateginya, dari strategi mendukung salah satu calon (Pemerintah) dan mendukung salah satu partai Islam secara terang-terangan seperti di era orde baru, berayun mendukung salah satu calon presiden dan wakil presiden lewat penguruspengurusnya. Bahkan ketua MUI dicalonkan sebagai wakil presiden 2019 bersama petahana, Ir Joko Widodo.

Di sinilah MUI memainkan perannya lewat pengurus-pengurus aktifnya. Memanfaatkan peran lembaga sebagai kuasa menurun yang berhubungan langsung dengan kuasa mendaki. Di samping itu, terdapat enam nama pengurus turut berperan aktif mendukung calon Prabowo dan Sandiaga Uno lewat Ijtima' Ulama I dan II yang dlaksanakan selama pemilihan Presiden dan Wakil Presiden RI 2019. Dalam forum tersebut diputuskan untuk mendukung Prabowo Subianto dan beberapa rekomendasi wakilnya. Meski seluruh rekomendasinya ditolak oleh Prabowo, namun beberapa tokoh yang tergabung dalam forum tersebut tetap bersikukuh mendukung Prabowo Subianto dan Sandiaga Uno sebagai bakal calon presiden dan wakil presiden. Bahkam Ijtima ulama dilanjutkan hingga ijtima ulama keempat.

Sebagian massa Islam memegang teguh hasil Ijtima' ulama sebagai semacam pedoman dalam memilih Presiden dan Wakil Presiden. Meski di kubu Joko Widodo dan Ma'ruf Amin, sebagian massa Islam, terutama jamaah Nahdlatul Ulama (NU) merasa peran Ma'ruf Amin baik sebagai ketua MUI maupun sebagai pengurus organisasi sangat representatif menjangkau kelompok Islam yang selama ini dianggap puritan dan patuh terhadap fatwa-fatwa yang dikeluarkan oleh MUI. Akhirnya suara Islam terpecah.

Kekuasaan menurun yang dilekatkan kepada ulama menemui persimpangan jalan. Otoritas ulama dipertanyakan oleh simpatisan masing-masing kubu. Kubu Jokowi-Amin mempertanyanyakan otoritas keilmuan dari ulama-ulama yang bergabung dalam kubu Prabowo-Sandi. Begitu juga sebaliknya, simpatisan dari kubu Prabowo-Sandi mempertanyakan kesholehan dari ulama-ulama yang berada di kubu Jowoki-Amin. 
Dengan sendirinya ketika kuasa menurun ini dibawa ke politik praktis seperti pada pilpres 2019 ini, polarisasi antar umat Islam semakin menajam. Tingkat kesakralan ulama yang selama ini dihormati oleh santri dan masyarakat secara gradul pudar seiring dinamika politik yang ditempuh. Bahkan di media sosial kritik masyarakat terhadap ulama dari masing-masing kubu tak terbendung. Bahkan hingga mengeluarkan ujaran kebencian. Misalnya salah seorang pria asal Provinsi Aceh yang mengedit foro Ma'ruf Amin sedang menggunakan kostum sinterklas. Kendati pria tersebut ditangkap.

\section{Legitimasi MUI lewat Fatwa dan Wacana}

Sebagaimana tesis Muhammad As'ad menyebut terdapat dua jenis media yang digunakan oleh MUI dalam memberikan panduan kepada masyarakat. Media ini adalah fatwa wacana dan wacana yang terdiri dari Rekomendasi (Tausiyah), Peringatan (Tadzkirah), Instruksi/Amanat (Amanah), Pernyataan Sikap, Banding (Himbauan), dan Pemikiran (Sumbangan Pemikiran).

Dilihat pada pemilihan serentak 2019 lalu, MUI memainkan legitimasinya lewat dua cara yaitu fatwa dan himbaunnya, ia berhasil memikat perhatian masyarakat yang saat itu sentiman agamanya sedang memuncak. Itu dibuktikan dari kronologi sejak pemilihan Gubernur Jakarta. Sedangkan wacana dimainkan lewat statmen pengurus di media massa maupun akun media sosial yang terferivikasi seperti twitter dan facebook. Tujuh pengurus aktif MUI tersebut secara terang-terangan terlibat dalam politik praktis saat pemilu 2019 yang lalu. Lewat dua jenis alat legitimasi itulah MUI memainkan perannya dalam politik Indonesia Mutakhir. Lewat itu juga MUI meraih simpati massa Islam yang yang sejalan dengan gagasan MUI sendiri.

Fatwa MUI juga memunculkan gelombang aksi 4 November (411) dan gerakan Islam 212, MUI memproduksi semacam kesadaran naif yaitu kesadaran tentang indentitas dan suku. Para politisi 'bersurban' mengekploitasi identitas untuk agenda politik. Lewat legitimasi fatwa itulah akhirnya persoalan identitas dan kesukuan semakin menjam di masyarakat. Padahal itu hanya hasil manipulasi identitas agama dari legitimasi MUI.

Sementara itu, dalam konteks distribusi wacana, pengurus MUI kerap mengguanakan media sosial selain media massa mainstream. Pengurus-pengurus MUI antara lain seperti $\mathrm{H}$. Tengku Zulkarnaen sangat aktif di media sosial, bahkan catatan-catatannya di media sosial kerap dianggap bermasalah karena diduga mengandung unsur ujaran kebencian, hoaks dan provakasi. Tengku misalnya pernah menulis terkait tujuh kontainer surat suara sudah tercoblos untuk pasangan Jokowi-Amin sebelum pemilihan presiden dan wakil presiden berlangsung. Buntutnya, Tengku Zulkarnaen akhirnya dilaporkan ke Bareskrim oleh pendukung Jokowi-Amin.

Selain Tengku Zul, Bachtiar Nasir (Ketua GNPF MUI) juga kerap melempar pernyataan yang mengundang kegaduhan lewat video-video di youtube dan facebook. Lewat legitimasi semacam itu Bachtiar Nastir memperoleh simpati dari massa Islam. Meski belakangan ia ditetapkan sebagai tersangka kasus pencucian uang dana Yayasan Keadilan untuk Semua. 


\section{MUI dan Indikator Bencana-Agama Perspektif Charles Kimball}

Apa yang ditakutkan oleh Charless Kimball (2002) sebagai lima syarat terjadinya praktik agama yang berubah jadi bencana berhubungan secara tidak langsung dengan peran MUI. Pertama, dalam kasus dugaan penistaan agama yang dilakukan oleh Basuki Tjahja Purnama lewat fatwa MUI. Pada saat itu umat Islam telah menjadi kekuatan massa yang seolah yakin dengan penuh kesadaran bahwa ada yang mengganggu klaim kebenarannya.

Ketika klaim kebenarannya terhadap tafsiran makna Qur'an (al-Maidah: 51) yang ditafsirkan kembali oleh oleh MUI sebagai penistaan, kehormatan umat Muslim merasa tersinggung dan dengan semarak turun ke jalan melakukan aksi dan protes. Fatwa yang memerintah umat Islam tersebut dikeluarkan persis ketika suhu politik pemilihan Gubernur dan wakil Gubernur DKI Jakarta memanas. Islam politik seperti menemukan girrah baru yakni bertarung kekuatan lewat aksi massa Islam. MUI sebagai inisiator semakin populis di kalangan umat Islam.

Kedua, MUI memanfaatkan fanatisme buta masyarakat yang meminggirkan peran rasionalisme kritis dalam melihat sebuah peristiwa. Baik lewat fatwa maupun pernyataan di media. Menurut Syafii Ma'rif, dalam situasi terpecah, sangat sulit menemukan pribadi-pribadi Muslim yang mampu secara psikokultural-religius bersikap tenang, objektif dan realistik. Kecuali umat Muslim yang tercerahkan dan terdidik (Kimball, 2002). Fanatisme buta terhadap salah seorang tokoh dan tafsir Islam tertentu menyebabkan rasionalitas umat Muslim tersisihkan. Psiko kultural religius menjadi labil dan jauh dari sikap realistis.

Ketiga, beberapa pengurus MUI menjejali narasi kebangkitan Islam yang bersilang dengan hadirnya Hizbuttahrir Indonesia (HTI). Narasi kebangkitan Islam menuju zaman ideal dimana keadilan, kemakmuran masyarakat akan terwujud jika Islam dijadikan sebagai ideologi negara tampak semakin menguat lewat ujaran-ujaran berbagai pengurus MUI dalam media sosial. sebagian kalangan Islam memimpikan sebuah pemerintahan Islami, antara lain yang 'diperjuangkan' oleh Al Qaida dan ISIS. Menurut Kimball, pemerintahan Islam versi Taliban (kelompok Islam ekstrim di Afghanistan) membahayakan penduduk di negara tersebut dan komunitas dunia secara umum (Kimball, 2002).

Salah seorang pengurus MUI yang ditengarai terlibat adalah Bachtiar Nasir yang mengelola Yayasan Indonesian Humanitarian Relief diduga mengirimkan bantuan logistik untuk mendukung pemberontak (ISIS) di Suriah. Yayasan tersebut aktif meminta sumbangan dari masyarakat Indonesia yang konon diklaim untuk membantu korban atau pengungsi sipil Suriah. Padahal nyatanya bantuan logistik dikirim malah untuk pemberontak.

Keempat, Menurut Kimball, menggunakan segala cara untuk meraih kekuasaan menjadi salah satu sebab agama menjadi bencana. Banyak penganut agama yang kehilangan fokus sehingga hanya memikirkan bagaimana cara mencapai tujuan. Ketika ada hal-hal kunci dalam agama (key feature of religion) yang tercederai, atau ingin dicapai, sebagian penganut agama berusaha mencapainya dengan menghalalkan segala cara. Mereka menjelma menjadi pemilik klaim kebenaran tunggal dan fanatik buta demi mencapai tujuan-tujuan itu, dan hal ini amat membahayakan umat manusia secara global (Kimball, 2002).

Dapat dilihat narasi-narasi yang dimainkan oleh pengurus MUI seperti Teungku Zulkarnaen bersimpati terhadap kelompok-kelompok penyebar hoaks 
seperti Saracen, Muslim Cyber Army (terorganisir), serta Jonru Ginting. Penyebaran hoaks dan fitnah terhadap tokoh-tokoh tertentu lewat media sosial memacing sentimen umat Islam. Hal tersebut merupakan strategi yang berbahaya bagi kebersatuan umat Islam sendiri. Akhirnya sebagian besar umat Islam tidak mampu berpikir jernih di tengah situasi politik di Indonesia.

Kelima, perang suci. Istilah 'perang suci' awalnya tertuju pada perang yang terjadi selama satu abad antara Islam dan Kristen (Perang Salib). Dalam 'perang suci', agama digunakan untuk mensakralkan peperangan. Menurut Kimball, mendeklarasikan perang sebagai sesuatu yang 'suci' adalah tanda bahwa sebuah pemahaman agama telah terkorupsi. Dalam pandangan Kimball, intisari agama yang otentik adalah ditemukannya perdamaian dan kedamaian batin personal bagi penganutnya serta koeksistensi antara manusia dengan seluruh makhluk lainnya.

Dalam temu alumni 212, yang diikuti dan diinisiasi oleh sebagian pengurus MUI seperti H. Zaitun Rasmin, hadir pula Neno Warisman yang membacakan puisi provokatif yang mengibaratkan umat Muslim harus melakukan perjuangan seperti Perang Badar. Menurut Neno, kondisi bangsa terpuruk lalu ia menganjurkan perang seolah umat Islam berada dalam keterancaman. Puisi tersebut menyebabkan pendukung Jokowi berang. Selain itu, hal sendana juga disampaikan oleh Amin Rais dalam pernyataannya di media massa. Amien Rais mengatakan siap di barisan pertama untuk melakukan Jihad dan Perang Total melawan pemerintah.

\section{Kesimpulan}

Sebagai pemegang otoritas kekuasaan menurun-mendaki para ulama dalam MUI telah menggunakannya dalam politik praktis pemilihan presiden dan wakil presiden 2019. Lewat otoritas kuasa menurun-mendaki itulah MUI melakukan mobilisasi dan mengerahakan massa turun ke jalan dalam aksi temu alumni 212. Selain itu MUI melakukan legitimasi kepada masyarakat untuk mendapatkan suara bagi calon yang diusung oleh masing-masing pengurus MUI. Apa yang disampaikan Kimball dalam lima prasarat agama menjadi bencana itu telah dimainkan oleh sebagian pengurus MUI. Dengan kata lain para oknum dalam tubuh MUI telah memanfaatkan legitimasinya lewat MUI untuk kepentingan politik praktisnya masing-masing. Sedangkan posisi partai Islam cenderung dipandang kurang potensial meraup suara mayoritas umat Islam Indonesia. Dari sana lah MUI juga berperan dalam keterbelahan dan atau polarisasi masyarakat Muslim akar rumput baik lewat fatwa dan pernyataan di media massa maupun dalam media sosial. Dampaknya hingga hari ini, umat Muslim punya kutub berseberangan melihat ulama panutannya masing-masing yang secara langsung terafiliasi dengan kekuatan politik tertentu. Polarisasi tersebut berpotensi menjadi pemicu konflik, baik antar agama maupun konflik antar umat Muslim sendiri. 


\section{Referensi}

As'ad, Muhammad. Religion and Politics In Indonesia Attitudes and Influences of The Indonesian Council of Ulama (MUI) on The General Election. Netherland: Thesis Leiden University, 2010.

Berger, Peter. Langit Suci: Agama sebagai Realitas Sosial. terj. Hartono, Jakarta: LP3ES, 1991.

Epley, Jennifer L. Voice of The Faithful: Religion and Politics in Contemporary Indonesia, The University of Michigan: Dissetation, 2010.

Harb, Ali. Nalar Kritis Islam Kontemporer. Terj. Umar Bukhari dan Ghazi Mubarak, Yogykarta: IRCiSoD, 2012.

Jurdi, Syarifudin. Pemikiran Politik Islam Indonesia. Yogyakarta: Pustaka Pelajar, 2008.

Kimball, Charles. Religion Becomes Evil: Five Warning Sign. Forest USA: Harpers Collins, 2002.

Kuntowijoyo. Dinamika Sejarah Umat Islam di Indonesia. Yogyakarta: IrCiSoD, 2017.

Mulkan, Abdul Munir. Perubahan perilaku politik dan polarisasi Umaat Islam 1965-1987: Dalam Perspektif Sosiologis. Jakarta: Rajawali Press, 1989.

(Yogyakarta: Kanisius, 2009)

Qodir, Zuly. Sosiologi Politik Islam: Kontestasi Islam Politik dan Demokrasi di Indonesia. Yogyakarta: Pustaka Pelajar, 2012.

Sangaji, Anto dkk. Bela Islam atau Bela Oligarki. Jakarta: Pustaka IndoPROGRESS, 2017

Ma'arif, Ahmad Syafi'i dkk. Politik Identitas dan Masa Depan Pluralisme. Jakarta: Yayasan Abad Demokrasi, 2012.

Mujani, Saiful. Muslim Demokrat: Islam Budaya Demokrasi dan Partisipasi Politik di Indonesia Pasca Orde Baru. Jakarta: Gramedia, 2007

Turner, Bryan S. Relasi Agama dan Teori Sosial Kontemporer. ter. Inyiak Ridwan Muzir, Yogyakarta: IrCiSod, 2012.

\section{Sumber Online Lainnya}

http//mui.or.id, diakses pada 13 Oktober 2019, pukul 13.47 WIB

https://www.republika.co.id/berita/nasional/politik/-ketua-mui-mui-tak-terlibatpolitik-praktis, diakses pada 13 Oktober 2019, Pukul 14.00 WIB

https://news.detik.com/berita/d-4326398/waketum-mui-saya-khawatir-212-kinibergeser-ke-politik-praktis, diakses pada 13 Oktober 2019, pukul 14.56 WIB

https://tirto.id/agenda-politik-di-balik-gnpf-ulama-alumni-212, diakses pada 15 Oktober 2019, pukul 14.00 WIB

https://www.cnnindonesia.com/nasional/gnpf-tarik-diri-dari-barisan-pendukungprabowo-sandi, diakses pada Selasa, 15 Oktober 2019, pukul 14.00 WIB https://www.voaindonesia.com/a/hasil-ijtima-ulama-ii-pastikan-dukungan-bagiprabowo-sandiaga/, diakses pada Selasa, 15 Oktober 2019, pukul 14.30 WIB

https://nasional.tempo.co/read/1127048/17-poin-pakta-integritas-ijtima-ulama-iiyang-disetujui-prabowo, diakses pada 14 Oktober 2019 pukul 12.32 
https://news.detik.com/berita/penyebar-video-maruf-amin-berkostum-sinterklasdiancam-5-tahun-bui, diakses pada 14 Oktober 2019 pukul 12.32 WIB https://m.republika.co.id/berita/nasional/politik/-dilaporkan-ke-bareskrim-inirespons-tengku-zulkarnain, diakses pada 14 Oktober 2019 pukul 12.32 https://www.cnnindonesia.com/nasional/polisi-tetapkan-eks-ketua-gnpf-ulamabachtiar-nasir-tersangka, diakses pada 14 Oktober 2019 pukul 12.32 https://www.cnnindonesia.com/nasional/polisi-tetapkan-eks-ketua-gnpf-ulamabachtiar-nasir-tersangka, diakses pada 14 Oktober 2019 pukul 12.32 https://nasional.tempo.co/read/902601/sindikat-konten-kebencian-saracenditangkap-polisi-siapa-mereka, diakses pada 14 Oktober 2019 pukul 14.32. https://news.detik.com/berita/puisi-neno-warisman-di-munajat-212-ramai-disorotini-isi-lengkapnya, diakses pada 14 Oktober 2019 pukul 14.32 https://www.cnnindonesia.com/nasional/amien-rais-kalau-diajak-jihad-sayapaling-depan, diakses pada 14 Oktober 2019 pukul 14.32 